\title{
Sulfonated Polyimide Membranes Derived from a Novel Sulfonated Diamine with Pendant Benzenesulfonic Acid for Fuel Cells
}

\author{
Khurram Liaqat ${ }^{1}$, Srosh Fazil ${ }^{1}$, Wajid Rehman ${ }^{2, *}(\mathbb{D})$, Shaukat Saeed ${ }^{3}$, Farid Menaa ${ }^{4, *(\mathbb{D},}$ \\ Syed Asim Hussain Shah ${ }^{5}$, Muhammad Nawaz ${ }^{6}$, Walaa Naji Alharbi ${ }^{7}$, Bouzid Menaa ${ }^{4}$ \\ and Muhammad Farooq ${ }^{8}$
}

check for

updates

Citation: Liaqat, K.; Fazil, S.; Rehman, W.; Saeed, S.; Menaa, F.; Shah, S.A.H.; Nawaz, M.; Alharbi, W.N.; Menaa, B.; Farooq, M. Sulfonated Polyimide Membranes Derived from a Novel Sulfonated Diamine with Pendant Benzenesulfonic Acid for Fuel Cells. Energies 2021, 14, 6050. https:// doi.org/10.3390/en14196050

Academic Editor: Roby Soni

Received: 25 July 2021

Accepted: 14 September 2021

Published: 23 September 2021

Publisher's Note: MDPI stays neutral with regard to jurisdictional claims in published maps and institutional affiliations.

Copyright: (c) 2021 by the authors. Licensee MDPI, Basel, Switzerland. This article is an open access article distributed under the terms and conditions of the Creative Commons Attribution (CC BY) license (https:/ / creativecommons.org/licenses/by/ $4.0 /)$.
1 Department of Chemistry, University of Poonch Rawalakot, Rawalakot 12350, Pakistan; imkhurram.wah@gmail.com (K.L.); srosh.chem@gmail.com (S.F.)

2 Department of Chemistry, Hazara University Mansehra, KPK, Mansehra 21120, Pakistan

3 Department of Chemistry, Pakistan Institute of Engineering and Applied Sciences, Islamabad 44000, Pakistan; inorganic.chemist78@gmail.com

4 Co-Pionneers of Spectro-Fluor ${ }^{\mathrm{TM}}$ (aka Carbone-Fluorine Spectroscopy), Fluorotronics-CIC, Inc., San Diego, CA 92037, USA; bouzid.menaa@gmail.com

5 Department of Physics and Chemistry, Universiti Tun Hussein Onn, Parit Raja 86400, Johor, Malaysia; achemist1986@gmail.com

6 Department of Chemistry, Balochistan University of Information Technology, Engineering and Management Sciences (BUITEMS), Airport Road Baleli, Quetta 87100, Pakistan; nawazhej@yahoo.com

7 Department of Chemistry, Science and Arts College, Rabigh Campus, King Abdulaziz University, Jeddah 80200, Saudi Arabia; wnhalharbe@kau.edu.sa

8 Department of Physics, Hazara University Mansehra, KPK, Mansehra 21120, Pakistan; farooq.muhammad30@gmail.com

* Correspondence: sono_waj@yahoo.com (W.R.); dr.fmenaa@gmail.com (F.M.)

Abstract: For improving the hydrolytic stability of sulfonated polyimides consisting of five membered anhydrides, novel sulfonated polyimides (NSPIs) were prepared via polymerization of $3,3^{\prime}, 4,4^{\prime}$ benzophenonetetracarboxylic dianhydride (BTDA), with a novel diamine monomer with a pendant sulfonic acid group and 4,4-oxydianiline. Water uptake of this NSPI with an excellent film-forming ability was almost equal to that of Nafion ${ }^{\circledR} 117$, while their ion exchange capacity (IEC) was $22 \%$ higher than Nafion ${ }^{\circledR} 117$. The loss in weight decreased by $53 \%$ and loss in IEC decreased by $66 \%$ compared to that of Nafion ${ }^{\circledR} 117$; both were used to quantitatively measure hydrolytic stability, and radical oxidative stability also increased by $75 \%$ when compared with Nafion ${ }^{\circledR} 117$. Mechanically, this NSPI was superior, and its proton conductivity was higher than Nafion ${ }^{\circledR} 117$ at elevated temperatures. All these improvements were due to the introduction of this pendant group. Taken together, we herein report a promising renewable energy source based on SPIs capable of displaying proton conductivity and enhanced hydrophilicity.

Keywords: sulfonated polyimide membranes; fuel cells; BTDA; renewable energy

\section{Introduction}

Awareness about the environment and availability of renewable energy sources are encouraging the people to find alternative solutions to fossil fuel. Possible available options are hydropower, wind energy, solar cells, and fuel cells. It takes 5 to 10 years to construct a dam as a source of hydropower and it also requires a large sum of finances. From the remaining options and for power generation, wind energy requires wind and solar cells require sun, respectively. This represents a limitation that is overcome by fuel cells. Depending on the availability of variety as well as provision of clean and efficient energy, fuel cell technology is one of the most promising alternatives [1-3]. Among the 
different available fuel cells, PEMFCs have been mostly used because of their high-power conversion, quick start up, low operating temperature, simplicity, and low cost [4]. The polymer electrolyte membrane (PEM) is a key part of PEMFCs, and perfluorinated sulfonic acid is mostly used for this because of its high proton conduction and appropriate chemical and thermal stability $[5,6]$. However, Nafion ${ }^{\circledR}$ is expensive and its proton conduction decreases as the temperature goes beyond $80^{\circ} \mathrm{C}$ [7-9]. PEMFCs are capable of operating at elevated temperature and display several advantages (e.g., enhanced operating voltage, performance, and $\mathrm{CO}$ tolerance). This results in extensive research for alternate PEM materials with suitable properties [10-14].

Among polymeric materials, polyimide is considered as a prospective candidate to substitute Nafion ${ }^{\circledR}$, due to the amide ring in its backbone. This amide ring in the polyimides provides tremendous mechanical strength, excellent chemical stability, and high thermal stability [15]. However, one of the major drawbacks of polyimides are the lack of proton conductivity. This shortcoming can be overcome by converting polyimide into sulfonated polyimides with the introduction sulfonic acid group, which not only promotes proton conduction, but also makes the polymer chain hydrophilic [16]. However, the hydrolytic stability of these sulfonated polyimides, which is associated with its mechanical stability in a strongly swelled state and its robustness in fuel cell conditions, is compromised due to the presence of a sulfonic acid group. At high water content and elevated temperatures, the aromatic imide linkage is vulnerable to hydrolysis resulting in depolymerization, due to which the mechanical strength of the SPI membranes decreases substantially [17].

Keeping the above points in mind, this paper reports the synthesis of a novel diamine with a sulfonic acid group on the ring other than the amino group [18]. This inclusion is expected to enhance the hydrolytic stability by diminishing the electrophilicity of the carbonyl from the imide ring $[19,20]$. Novel sulfonated diamines (NSDAs) were characterized by nuclear magnetic resonance $\left({ }^{1} \mathrm{H}\right.$ NMR and ${ }^{13} \mathrm{C}$ NMR) and Fourier-transform infrared spectroscopy (FTIR). NSDAs were also investigated for their thermal stability, absorption, proton conductivity, and IEC. Eventually, the prepared NSPIs (and a non-sulfonated diamine) resulted in thin films, which were then characterized by FTIR.

\section{Experimental}

\subsection{Materials}

3,3',4,4'-benzophenonetetracarboxylic dianhydride (BTDA; 96\%), 4,4'-oxydianiline (ODA, 97\%), dimethylacetamide (DMAc; $99.8 \%$, water content $<0.005 \%$ ), 2-formylbenzenesulfonic acid sodium salt (FBSASS, 95\%), and Nafion ${ }^{\circledR} 117$ were all purchased from Sigma-Aldrich, USA. Ethanol was bought from Lab-Scan, Ireland.

\subsection{Synthesis of Novel Sulfonated Diamine (NSDA)}

After preheating the reaction flask at $50{ }^{\circ} \mathrm{C}$, it was purged with nitrogen for $30 \mathrm{~min}$. Then, $0.24 \mathrm{~mol}$ of aniline was taken as a solvent in the reaction flask and $0.08 \mathrm{~mol}$ of 2-Formylbenzenesulfonic acid sodium salt along with $1.07 \mathrm{~g}$ of aniline hydrochloride were added into it. The reaction mixture was then refluxed at $120^{\circ} \mathrm{C}$ under the nitrogen atmosphere for $3 \mathrm{~h}$. After cooling, $30 \mathrm{~mL}$ of ethanol was added to this mixture, which was then heated to $80{ }^{\circ} \mathrm{C}$ again. It was kept for overnight at room temperature (RT). Purple crystals formed were filtered and washed for the removal of traces of reactants. The recrystallization of crude materials was carried out in ethanol [18]. The synthesis of the NSDA is illustrated in Figure 1. 


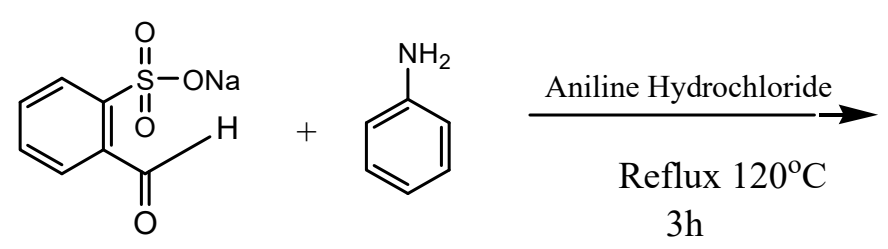<smiles>Nc1ccc(C(c2ccc(N)cc2)c2ccccc2S(=O)(=O)O)cc1</smiles>

Figure 1. Synthesis of novel sulfonated diamine (NSDA).

\subsection{Synthesis of Novel Sulfonated Polyimide}

$m$-cresol was taken in a round bottom flask, in which NSDA and triethylamine were dissolved by stirring. Later, 4,4'-oxydianiline (ODA) and 4,4'-benzophenonetetracarboxylic dianhydride (BTDA) were dissolved into this mixture under continuous stirring and in the presence of $\mathrm{N}_{2}$ for $24 \mathrm{~h}$. The prepared films of viscous novel sulfonated polyamic acid (NSPAA) were casted by the solvent elution technique and subsequently thermally imidized to NSPIs. NSPAA films were heated to $80^{\circ} \mathrm{C}$ for $1 \mathrm{~h}$, this temperature was raised to $200{ }^{\circ} \mathrm{C}$ at a heating rate of $2{ }^{\circ} \mathrm{C} / \mathrm{min}$, and maintained for $24 \mathrm{~h}$ after which it was dropped to $50{ }^{\circ} \mathrm{C}$ at a rate of $1{ }^{\circ} \mathrm{C} / \mathrm{min}$. As obtained, the NSPI films were in the form of benzenesulfonic sodium acid salt and were then converted into benzenesulfonic acid by dipping into $1 \mathrm{M} \mathrm{HCl}$ solution for $6 \mathrm{~h}$ (Figure 2). The same procedure can be used to synthesize NSPIs with different concentrations of NSDA [21].

\subsection{Characterization Methods}

\subsubsection{Spectroscopy}

NSDA formation was confirmed by ${ }^{13} \mathrm{C}$ NMR (NMR-200, OXFORD). To confirm the thermal imidization (process), FTIR spectroscopy (Mattson Galaxi 6030, Mattson Instruments Inc., Madison, WI, 53717) was used.

\subsubsection{Oxidative Stability}

To study the oxidative stability, NSPI membranes were dissolved into Fenton reagent at RT, following a previously described method [22].

\subsubsection{Hydrolytic Stability}

This was measured in terms of the loss in weight and loss in ion exchange capability of NSPI membranes at $140{ }^{\circ} \mathrm{C}$ under pressurized steam, following a previously reported method [23].

\subsubsection{Water Uptake}

A standard test based on ASTM D570-98(2010)e1 was carried out for determining the water uptake (WU) value of NSPI membranes, following previously published methods $[24,25]$. NSPI membranes were heated in an oven at $105^{\circ} \mathrm{C}$ for $1 \mathrm{~h}$, followed by heating at $50{ }^{\circ} \mathrm{C}$ for $24 \mathrm{~h}$. After cooling to RT, these membranes were weighted and dipped into deionized water for $24 \mathrm{~h}$. After $24 \mathrm{~h}$, these membranes were cleaned with the tissue paper and weighted again. The WU value was determined by applying the following Formula (1):

$$
\mathrm{WU}(\%)=\frac{\mathrm{W}_{\mathrm{w}}-\mathrm{W}_{\mathrm{d}}}{\mathrm{W}_{\mathrm{d}}} \times 100
$$

where $W_{w}$ is the weight of wet membranes, and $W_{d}$ is the weight of the dry membranes. 
<smiles>Nc1ccc(Oc2ccc(C(c3ccc(N)cc3)c3ccccc3S(=O)(=O)O)cc2)cc1</smiles><smiles>Nc1ccc(Oc2ccc(NC(=O)c3cc(C(=O)c4ccc(C(=O)O)c(C(=O)Nc5ccc(C(c6ccc(N)cc6)c6ccccc6S(=O)(=O)O)cc5)c4)ccc3C(=O)O)cc2)cc1</smiles>

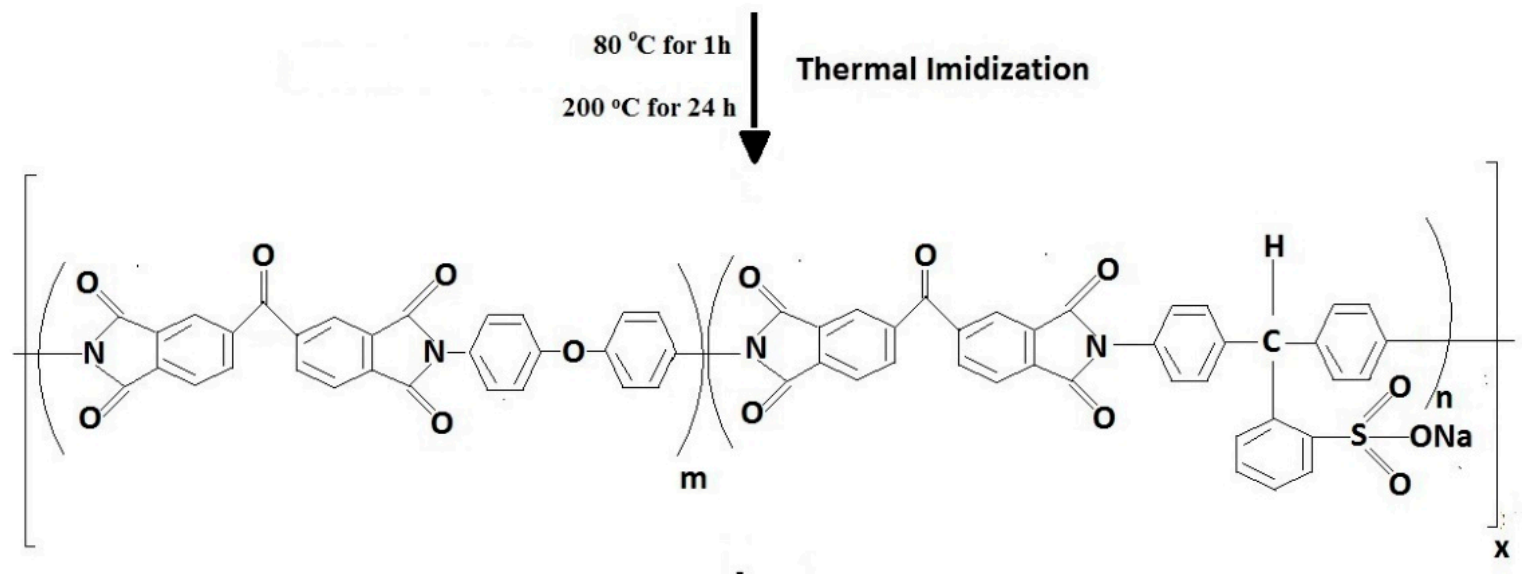

Conversion of $\mathrm{SO}_{3} \mathrm{Na}$ into $\mathrm{SO}_{3} \mathrm{H}$ $1 \mathrm{M} \mathrm{HCl}$ for $6 \mathrm{hrs}$

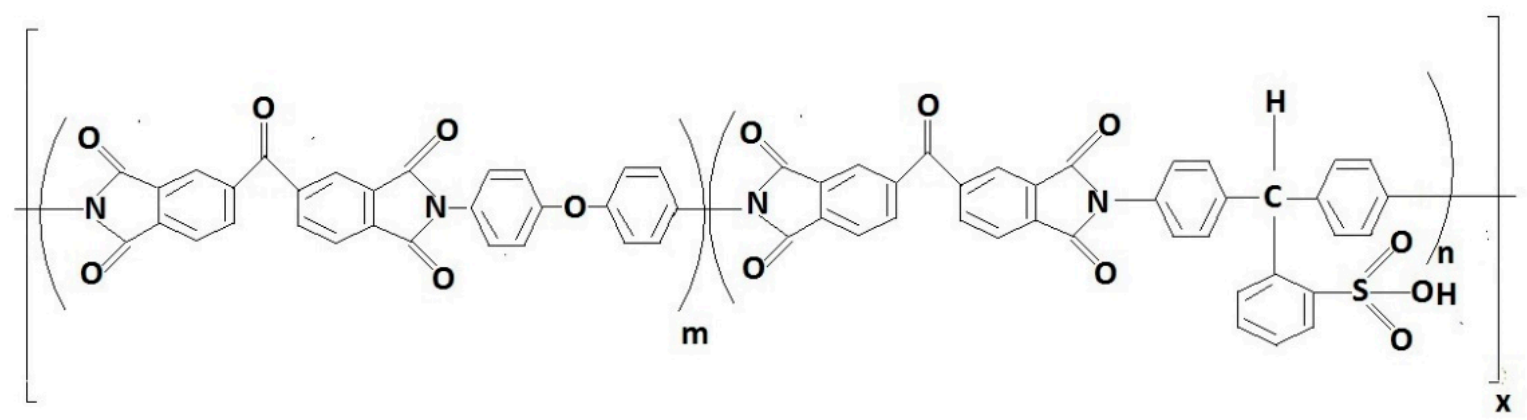

Figure 2. Synthesis of a novel sulfonated polyimide (NSPI).

\subsubsection{Ion Exchange Capacity}

The ion exchange capacity (IEC) was measured by titration method, as previously described [21]. Briefly, a weighted sample of membrane was dipped into saturated solution of sodium chloride at $50{ }^{\circ} \mathrm{C}$ for $48 \mathrm{~h}$, resulting in the replacement of $\mathrm{H}^{+}$ions by $\mathrm{Na}^{+}$ions, as illustrated in the following reaction:

$$
-\mathrm{SO}_{3} \mathrm{H} \rightarrow-\mathrm{SO}_{3} \mathrm{Na}
$$


Subsequently, 0.01 M sodium hydroxide $(\mathrm{NaOH})$ was used to titrate these $\mathrm{H}^{+}$ions in the presence of bromophenol blue indicator. IEC of membranes was calculated by using Formula (2):

$$
\operatorname{IEC}(\mathrm{meq} / \mathrm{g})=\frac{\mathrm{X} \times \mathrm{N}_{\mathrm{N}_{\mathrm{a}} \mathrm{OH}}}{\text { Weight of Polymer }}
$$

where $\mathrm{X}$ is the volume of $\mathrm{NaOH}$ consumed, and $\mathrm{N}_{\mathrm{NaOH}}$ is the normality.

\subsubsection{Thermogravimetric Analysis (TGA)}

TGA was performed by using the instrument NETZSCH TG 209 F1 at a heating rate of $10^{\circ} \mathrm{C} / \mathrm{min}$ in the range of $30{ }^{\circ} \mathrm{C}$ to $800^{\circ} \mathrm{C}$ in a nitrogen atmosphere.

\subsubsection{Proton Conductivity}

Proton conductivity (PC) was measured by the Auto Lab Impedance Analyzer and conductivity cell. The following formula was used for converting resistance into conductance:

$$
\mathrm{PC}=\left(\frac{1}{\Omega}\right) \times\left(\frac{\mathrm{d}}{\mathrm{A}}\right)
$$

where $\Omega$ is resistance, $\mathrm{d}$ is thickness, and A is the cross-sectional area of the NSPI films, respectively [26].

\subsubsection{Fuel Cell Performance}

The catalyst-coated gas diffusion layer (CCGDL) method was made of Teflon Treated Toray Carbon Paper 060 (TGP-H-060) that was 10\% wet proofed (TGP-H60, PEMEAS, E-TEK Division). This carbon fiber composite is suitable for use as a catalyst backing layer and represents a great low-cost alternative to conventional woven carbon cloth gas diffusion layer (GDL) materials. The Teflon gives the carbon material a hydrophobic property to better function as an electrode backing material. Herein, the TGP-H-060 was coated with a catalyst layer spray deposited from a heterogeneous mixture composed of $20 \% \mathrm{Pt} / \mathrm{C}\left(0.40 \mathrm{mg} / \mathrm{cm}^{2}\right)$ and $30 \mathrm{wt} \%$ Nafion ${ }^{\circledR}$ ionomer (as a solid) in an aqueous solution of isopropanol. NSPI (thickness $\frac{1}{4} 30 \mathrm{~mm}$ ) was sandwiched at high pressure (w1280 psi, $\left.90 \mathrm{~kg} / \mathrm{cm}^{2}\right)$ between two CCGDLs for $90 \mathrm{~s}$ at $135^{\circ} \mathrm{C}$. A triple serpentine $\left(5 \mathrm{~cm}^{2}\right)$ single cell (Teledyne Energy Systems, Inc., Los Angeles, CA, USA) was used for the fuel cell polarization measurement. The fuel cell operated in a $\mathrm{H}_{2}$ (anode)- $\mathrm{O}_{2}$ mixture (cathode) with $200 \mathrm{~mL} / \mathrm{min}$, at room temperature and constant pressure. Fully humidified fuel cell reactant gases were supplied, and the temperature was set at $50{ }^{\circ} \mathrm{C}$ in a co-flow manner. All polarization curves $(n=8)$ were obtained in the same manner (to confirm the polarization behavior), i.e., by reducing the cell potential with $30 \mathrm{~s}$ hold times, starting from open circuit voltage (OCV) to $0.2 \mathrm{~V}$ in $50 \mathrm{mV}$ increments [27].

\section{Results and Discussion}

\subsection{Spectroscopic Analysis}

The composition and structure of the NSDAs were studied by ${ }^{13} \mathrm{C}-\mathrm{NMR}$ (Figure 3). Carbon atoms numbered as " 1 and 10 " are represented by a peak at $146.55 \mathrm{ppm}$. Carbons numbered as "2, 6, 9, and 11" are represented by a peak at 118.43 ppm, whereas carbons numbered as " $3,5,8$, and 12 " are expressed by a peak at $130.43 \mathrm{ppm}$. Carbons numbered as " 4 and 7 " are represented by a peak at $129.03 \mathrm{ppm}$. The peak at $139.22 \mathrm{ppm}$ is assigned to the carbon atom numbered as "13", which is attached to sulfonic acid group $\left(\mathrm{SO}_{3} \mathrm{H}\right)$. Carbons marked as "14 and 15" are represented by peaks at 141.92 ppm and 138.21 ppm, respectively. Carbons marked as "16, 17, 18, and 19" are displayed by peaks at $125.55 \mathrm{ppm}$, 131.38 ppm, 127.33 ppm, and 49.13 ppm, respectively. The solvent is represented by a peak at $40.08 \mathrm{ppm}$ [15]. 


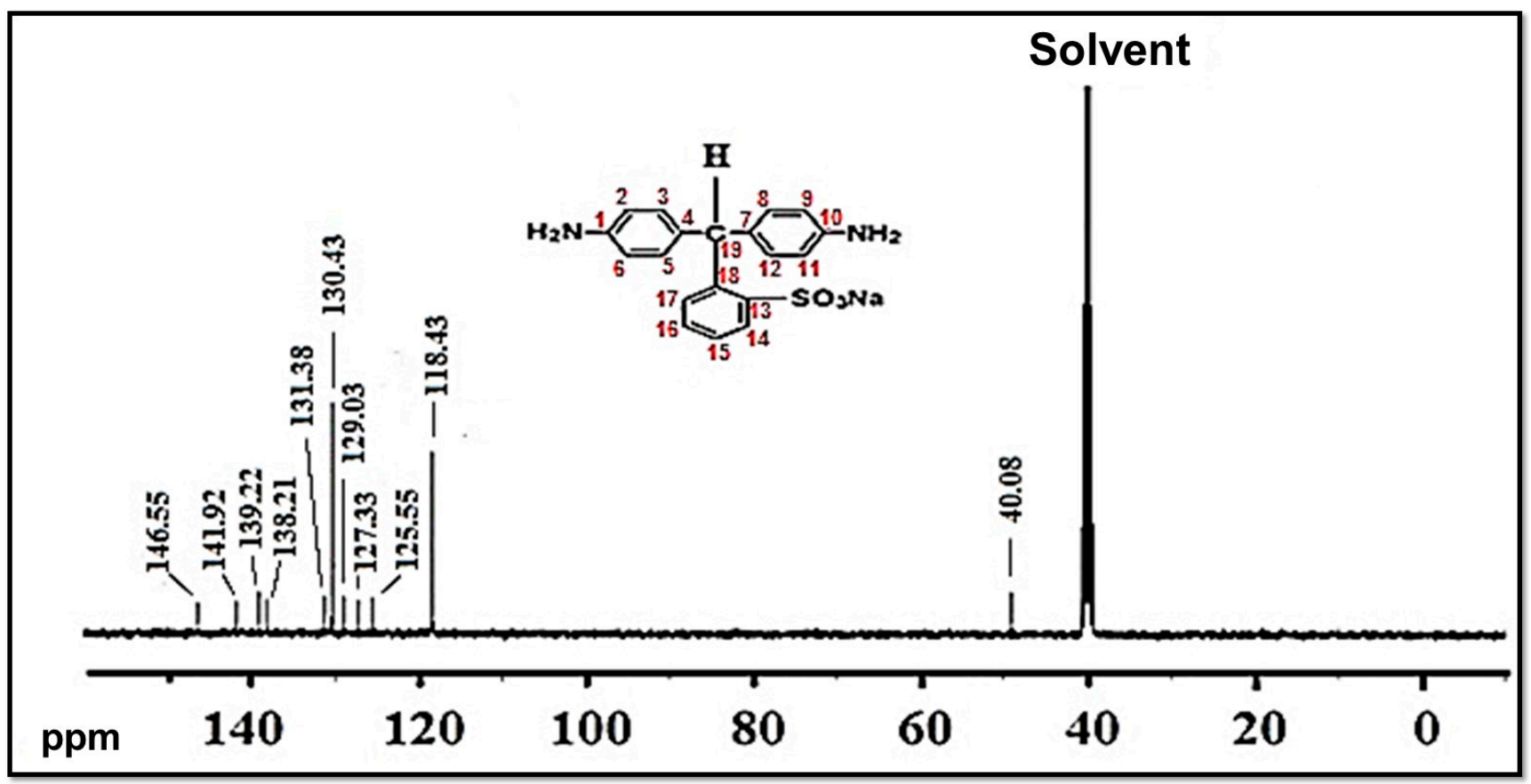

Figure $3 .{ }^{13} \mathrm{C}$ NMR of a novel sulfonated diamine (NSDA).

Thermal imidization of NSPAA into a NSPI was confirmed by FTIR spectroscopy. In Figure 4, peaks at $1780 \mathrm{~cm}^{-1}$ and $1740 \mathrm{~cm}^{-1}$ are attributed to $\mathrm{C}=\mathrm{O}$ asymmetric and symmetric stretching of imide, respectively. The peak at $1670 \mathrm{~cm}^{-1}$ is assigned to the $\mathrm{C}=\mathrm{O}$ stretching vibration of BTDA. The C-N-C bond of imide is represented by a peak at $1345 \mathrm{~cm}^{-1}$. The thermal imidization of NSPPA into NSPI is confirmed by these peaks [28]. The peak at $1250 \mathrm{~cm}^{-1}$ is due to the $\mathrm{SO}_{3} \mathrm{H}$ group [29].

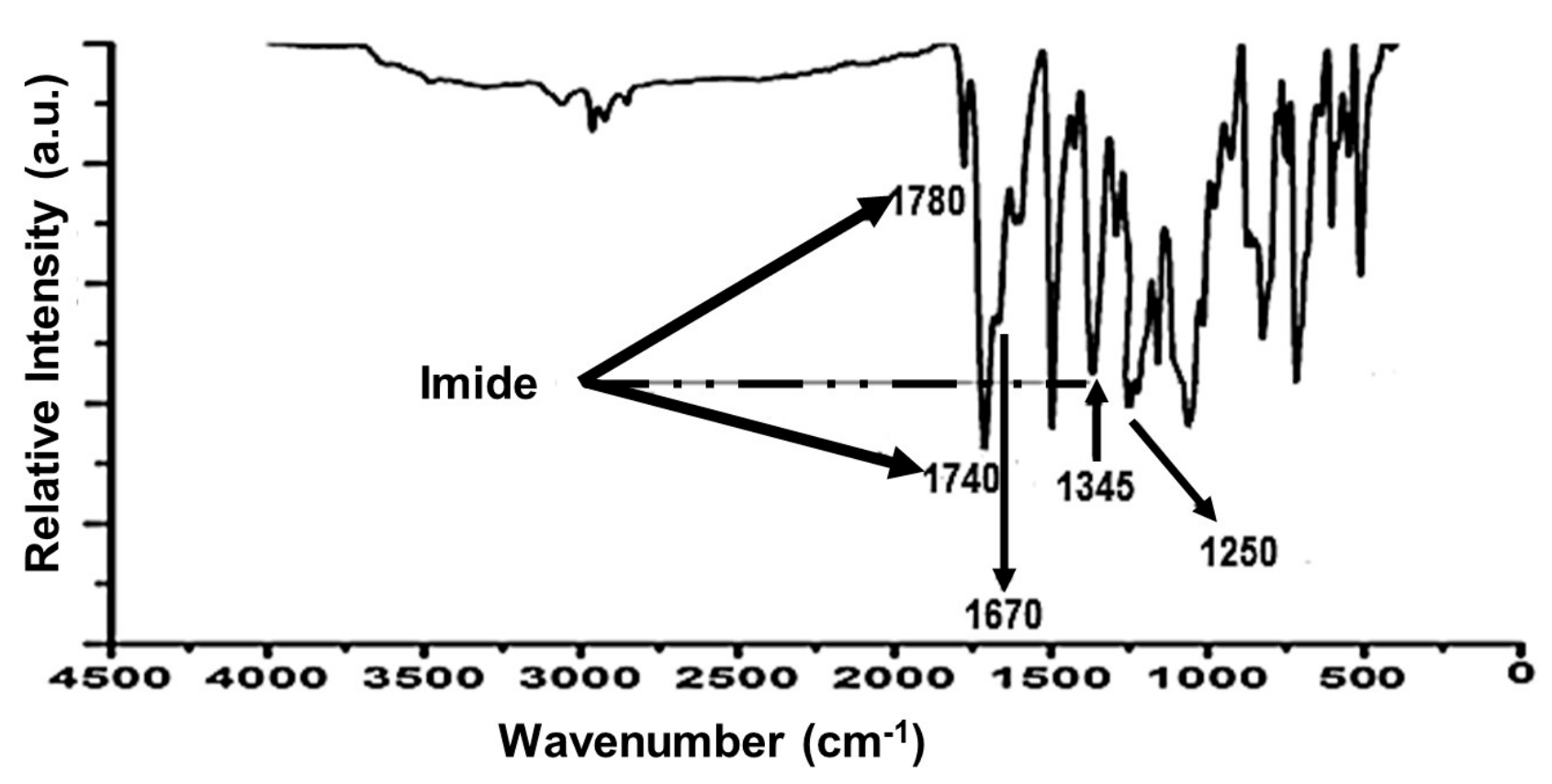

Figure 4. FTIR of a novel sulfonated polyimide (NSPI). 


\subsection{Ion Exchange Capacity (IEC)}

In fuel cells, the IEC value of SPIs is used for ascertaining the actual ion exchange sites for proton conduction. It is a measurement of presence of $-\mathrm{SO}_{3} \mathrm{H}$ groups and free protons of these groups. In moisture condition, SPIs membranes swell to conduct the protons, as their $-\mathrm{SO}_{3} \mathrm{H}$ groups are hydrophilic in nature. Generally, a higher IEC results in increased proton conductivity, but in case of SPIs, it lowers their hydrolytic stability. Therefore, both improved hydrolytic stability and proton conductivity contents of the $-\mathrm{SO}_{3} \mathrm{H}$ group need optimization, which can be achieved by adjusting the ratio of sulfonated and unsulfonated diamine [30]. Table 1 indicates that as NSDA content increases from 10 to $50 \mathrm{~mole} \%$, IEC value increases from 1.06 to $1.30 \mathrm{meq} / \mathrm{g}$, whereas the film-forming capacity decreases. The IEC value in our case is small as compared to Umsarika et al.'s work, in which they synthesized sulfonated poly(aromatic imide-co-aliphatic imide) based on BTDA, which might be due to presence of aromatic-co-aliphatic imide linkages [31].

Table 1. Water uptake, ion exchange capacity, and film=forming ability of NSPI membranes.

\begin{tabular}{lccc}
\hline \multicolumn{1}{c}{ Membranes } & $\begin{array}{l}\text { WU } \\
\mathbf{( \% )}\end{array}$ & $\begin{array}{c}\text { IEC } \\
(\mathbf{m e q} / \mathbf{g})\end{array}$ & FFA \\
\hline $\begin{array}{l}\text { NSPI 10 } \\
\text { [(NSDA-ODA-10/90) BTDA] }\end{array}$ & 31.81 & 1.09 & Excellent \\
\hline $\begin{array}{l}\text { NSPI 30 } \\
\text { [(NSDA-ODA-30/70) BTDA] }\end{array}$ & 32.92 & 1.25 & Brittle \\
\hline $\begin{array}{l}\text { NSPI 50 } \\
\text { [(NSDA-ODA-50/50) BTDA] }\end{array}$ & 36.50 & 1.31 & Very brittle \\
\hline Nafion ${ }^{\circledR} 117$ & 33.98 & 0.89 & Excellent \\
\hline $\begin{array}{l}\text { WU: water uptake; IEC: ion exchange capacity; FFA: film-forming capacity. } \\
\end{array}$
\end{tabular}

\subsection{Water Uptake}

Water uptake (WU) is an essential parameter of the NSPI membranes in fuel cell application, which was determined at RT $\left(25-30^{\circ} \mathrm{C}\right)$. Higher WU means more ionic content and, ultimately, an increase of proton conductivity. WU is usually determined by the ion exchange capacity (IEC) or $\mathrm{SO}_{3} \mathrm{H}$ content in the polymer. Nevertheless, an increase in WU also results from flexibility of the polymer backbone that causes the membrane to swell. Generally, water uptake of SPIs is lower than the Nafion ${ }^{\circledR}$ because of crosslinking, due to which swelling of the membrane is restricted [32]. NSPIs with different percentages of NSDA are presented in Table 1, which concluded that the WU of NSPI membranes is directly proportional to the NSDA contents and is almost the same as that of Nafion ${ }^{\circledR} 117$. This higher WU is due to the presence of the pendant sulfonic acid group and agrees with the previous study of Yin et al., in which the authors reported that the water uptake value of SPIs varied with the position of the pendant sulfonic acid group directly attached to those SPIs [33]. The WU value that we obtained is far better than that of Umsarika et al.'s work, in which they reported synthesized sulfonated poly (aromatic imide-co-aliphatic imide) based on BTDA [31].

\subsection{Film-Forming Ability (FFA)}

Although both NSPI 10 (with NSDA/ODA in 10/90 ratio) and Nafion ${ }^{\circledR} 117$ exhibited outstanding FFA, the increase of SDA content up to $50 \mathrm{~mol} \%$ (NSPI 50) caused a too brittle film (Table 1).

\subsection{Oxidative Stability}

The ${ }^{\bullet} \mathrm{OH}$ and $\bullet{ }^{\bullet} \mathrm{OH}$ radicals form during the fuel cell operation attacks on the polymer backbone and deteriorate NSPIs [34]. The ex-situ oxidative stability of PEM is usually evaluated by Fenton's test (i.e., NSPIs are submerged into Fenton's reagent (30\% 
$\mathrm{H}_{2} \mathrm{O}_{2}$ containing 30 ppm $\mathrm{FeSO}_{4}$ ) at RT, and the time taken from breaking $\left(\tau_{1}\right)$ to complete dissolution $\left(\tau_{2}\right)$ is used to estimate the oxidative stability of the NSPIs).

Data summarized in Table 2 show that NSPIs are superior to Nafion ${ }^{\circledR} 117$ in terms of oxidative stability. Additionally, oxidative stability is enhanced as the SDA content of NSPIs increased, and this is most likely due to pendant sulfonic acid, which could protect the polymer main chain from being attacked by water molecules containing highly oxidized radical species [35].

Table 2. Oxidative stability of NSPI membranes as measured by Fenton's reagent.

\begin{tabular}{|c|c|c|c|c|}
\hline \multirow[b]{2}{*}{ Membranes } & \multicolumn{2}{|c|}{$\begin{array}{l}\text { Oxidative Stability } \\
\text { (Time) }\end{array}$} & \multicolumn{2}{|c|}{$\begin{array}{l}\text { Hydrolytic Stability } \\
\text { (Loss \%) }\end{array}$} \\
\hline & $\tau_{1}{ }^{a}(h)$ & $\tau_{2}^{b}(h)$ & Weight & IEC \\
\hline $\begin{array}{l}\text { NSPI } 10 \\
\text { [(NSDA-ODA-10/90) BTDA] }\end{array}$ & 24 & 38 & 0.98 & 1.08 \\
\hline $\begin{array}{l}\text { NSPI } 30 \\
\text { [(NSDA-ODA-30/70) BTDA] }\end{array}$ & 28 & 46 & 0.85 & 0.91 \\
\hline $\begin{array}{l}\text { NSPI } 50 \\
\text { [(NSDA-ODA-50/50) BTDA] }\end{array}$ & 32 & 56 & 0.73 & 0.81 \\
\hline Nafion ${ }^{\circledR} 117$ & 2 & 10 & 1.50 & 1.80 \\
\hline
\end{tabular}

\subsection{Hydrolytic Stability}

NSPIs can also be deteriorated by hydrolysis, as carbonyl carbons of imide rings have the affinity for water molecules resulting in the disclosure of the ring, and subsequently the scissoring of the polymer backbone. The hydrolytic stability of SPIs depends on the following: (a) the distancing of the sulfonic acid group from the imine functionality by the presence of the spacer group, thereby hindering protonation of the carbonyl group, which results in decreased hydrolytic stability; (b) strength of the basic nitrogen [36-39]. Another factor that enhances the hydrolytic stability of side chain-type SPIs is their ability to form microphase-separated structures [40]. Keeping these two factors in mind, we synthesized NSDAs with the sulphonic acid group hanging as a side chain. Their hydrolytic stability was estimated in terms of the loss in weight and loss in IEC at $140{ }^{\circ} \mathrm{C}$ under pressurized steam. The results, presented in Table 2, indicate that NSPIs are superior to Nafion ${ }^{\circledR} 117$ in terms of hydrolytic stability, which increased with the increase in sulfonated content. This is evidenced from the fact that, when the SDA content increased from 10 to $50 \mathrm{~mol} \%$, the loss in weight and the loss in IEC decreased from $0.97 \%$ to $0.72 \%$ and from $1.07 \%$ to $0.80 \%$, respectively. This might be explained by the difficulty of nucleophilic attack of the $-\mathrm{OH}$ ion on the imide bond due to the specific structure of the SDAs. Consequently, - $\mathrm{OH}$ attacked the sulphonic acid group, which is not a part of polymer backbone.

\subsection{Thermal Stability}

Thermal gravimetric analysis (TGA) was carried out for evaluating the effect of varying SDA/ODA contents on the ex-situ thermal stability of BTDA-based NSPIs membranes. Figure 5 shows that the TGA stability of NSPI is higher compared to that of Nafion ${ }^{\circledR}$ and it is inversely linked to the SDA content (i.e., TGA stability decreases with the increase in SDA content). 


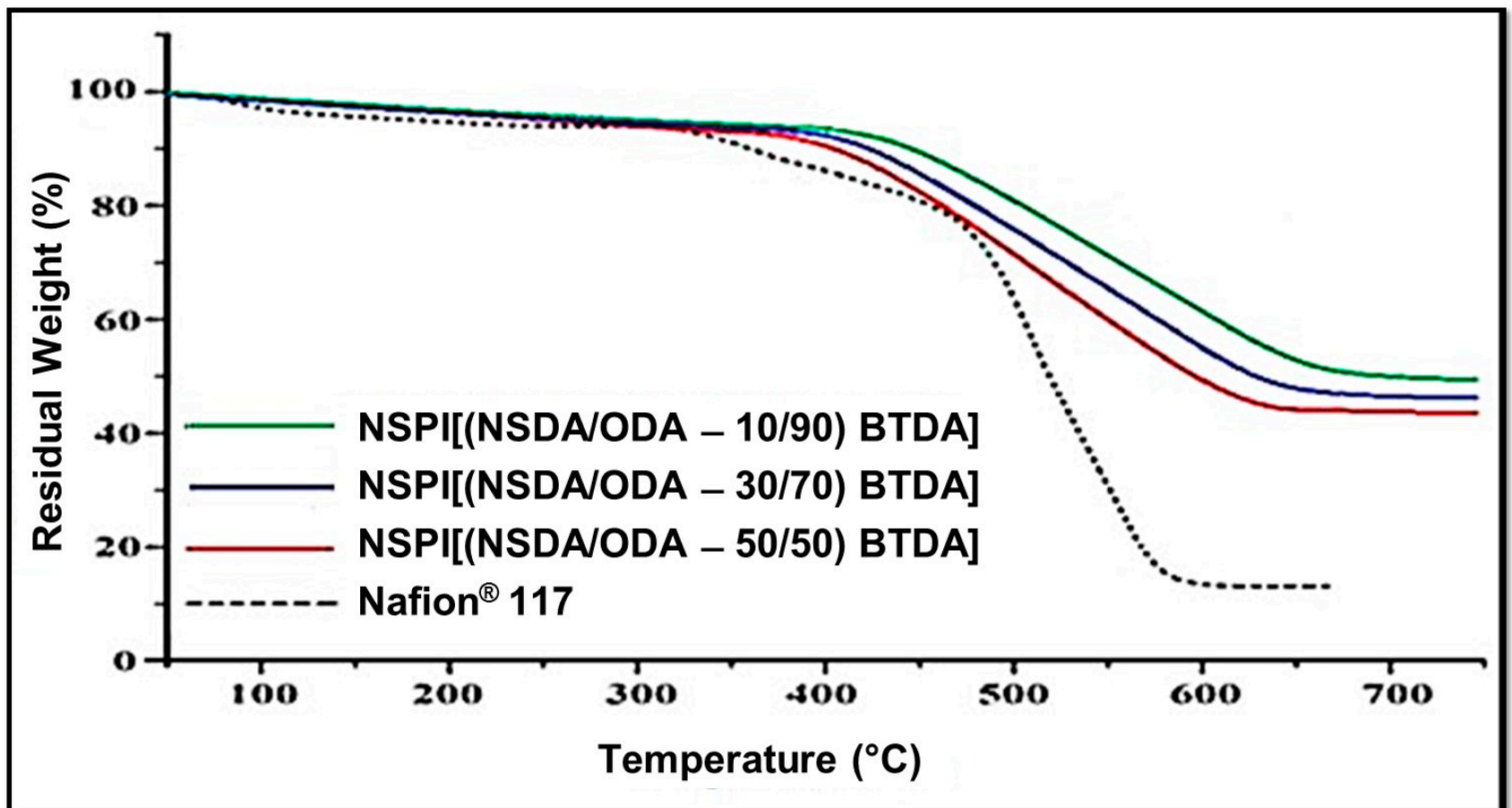

Figure 5. TGA curve of NSPIs and Nafion ${ }^{\circledR} 117$ membranes.

Initial weight loss, which starts at $100{ }^{\circ} \mathrm{C}$, is due to moisture content, whereas weight loss due to $\mathrm{SO}_{3} \mathrm{H}$ decomposition starts at $220^{\circ} \mathrm{C}$, and with the increase in SDA content this weight loss increases. The third weight loss related to the polymer backbone degradation starts at $550{ }^{\circ} \mathrm{C}$ for NSPI membranes, confirming that NSPIs membranes are thermally stable [36]. As the PEMFC working temperature is far below $200{ }^{\circ} \mathrm{C}$, the thermal stability of these NSPIs is high enough for practical purposes.

\subsection{Mechanical Stability}

Since NSPI 10 (with $10 \mathrm{~mol} \%$ SDA content/[(NSDA/ODA-10/90) BTDA]) shows excellent FFA, we then characterized its mechanical properties (stability) in comparison with Nafion ${ }^{\circledR}$ 117. As shown in Table 3, NSPI 10 is mechanically stable as compared to Nafion ${ }^{\circledR} 117$. Additionally, a decrease in young modulus, tension, and elongation by $1.94 \%$, $2.51 \%$, and $10.52 \%$, respectively, was observed after $400 \mathrm{~h}$ of soaking time. These decreases are negligible after keeping in mind the soaking time of $400 \mathrm{~h}$.

Table 3. Comparison of NSPI 10 and Nafion ${ }^{\circledR} 117$ mechanically.

\begin{tabular}{lcccc}
\hline Membrane & $\begin{array}{c}\text { Soaking } \\
\text { Time } \\
\mathbf{( h )}\end{array}$ & $\begin{array}{c}\text { Young's } \\
\text { Modulus } \\
\mathbf{( G P a )}\end{array}$ & $\begin{array}{c}\text { Maximum } \\
\text { Stress } \\
\mathbf{( M P a )}\end{array}$ & $\begin{array}{c}\text { Elongation } \\
\text { at Break } \\
\mathbf{( \% )}\end{array}$ \\
\hline & 0 & 2.58 & 159.00 & 19 \\
NSPI 10 & 100 & 2.57 & 158.00 & 19 \\
[(NSDA/ODA-10/90) BTDA] & 200 & 2.56 & 157.00 & 18 \\
& 300 & 2.55 & 156.00 & 18 \\
\hline Nafion $^{\circledR} 117$ & 400 & 2.53 & 155.00 & 17 \\
\hline
\end{tabular}

\subsection{Proton Conductivity}

The hydrophilic segment of SPIs is responsible for the conduction of protons, resulting from the movement of protons between ionic clusters made up of polar groups such as 
$-\mathrm{SO}_{3} \mathrm{H}$. The number of these ionic clusters is dependent on the number of $-\mathrm{SO}_{3} \mathrm{H}$ groups and water content in SPI membranes [23,41]. The greater the number of $-\mathrm{SO}_{3} \mathrm{H}$ groups, the greater the generation of free protonic ions, ionic clusters, and free volume will be, resulting in the improved mobility of free protons, through the ionic clusters in the form of hydronium ions [42]. Temperature-dependent NSPIs proton conductivity is shown in the Figure 6, which represents that proton conductivity of the NSPI membranes increases with the increase in SDA (hydrophilic segment) content. In the studied temperature range, proton conductivity varies directly with the temperature, which is lower for all NSPI membranes having pendent sulfonic acid group membranes as compared to Nafion ${ }^{\circledR} 117$, which might be due to improperly connected hydrophilic ionic domains resulting in the lack of ionic channels for proton transport [43]. Conversely, the rates of proton conductivity for NSPI membranes are likely to be higher (by extrapolation) than Nafion ${ }^{\circledR} 117$ at elevated temperatures $\left(>110^{\circ} \mathrm{C}\right)$, making them more adaptive at extreme temperatures as compared to Nafion ${ }^{\circledR}$.

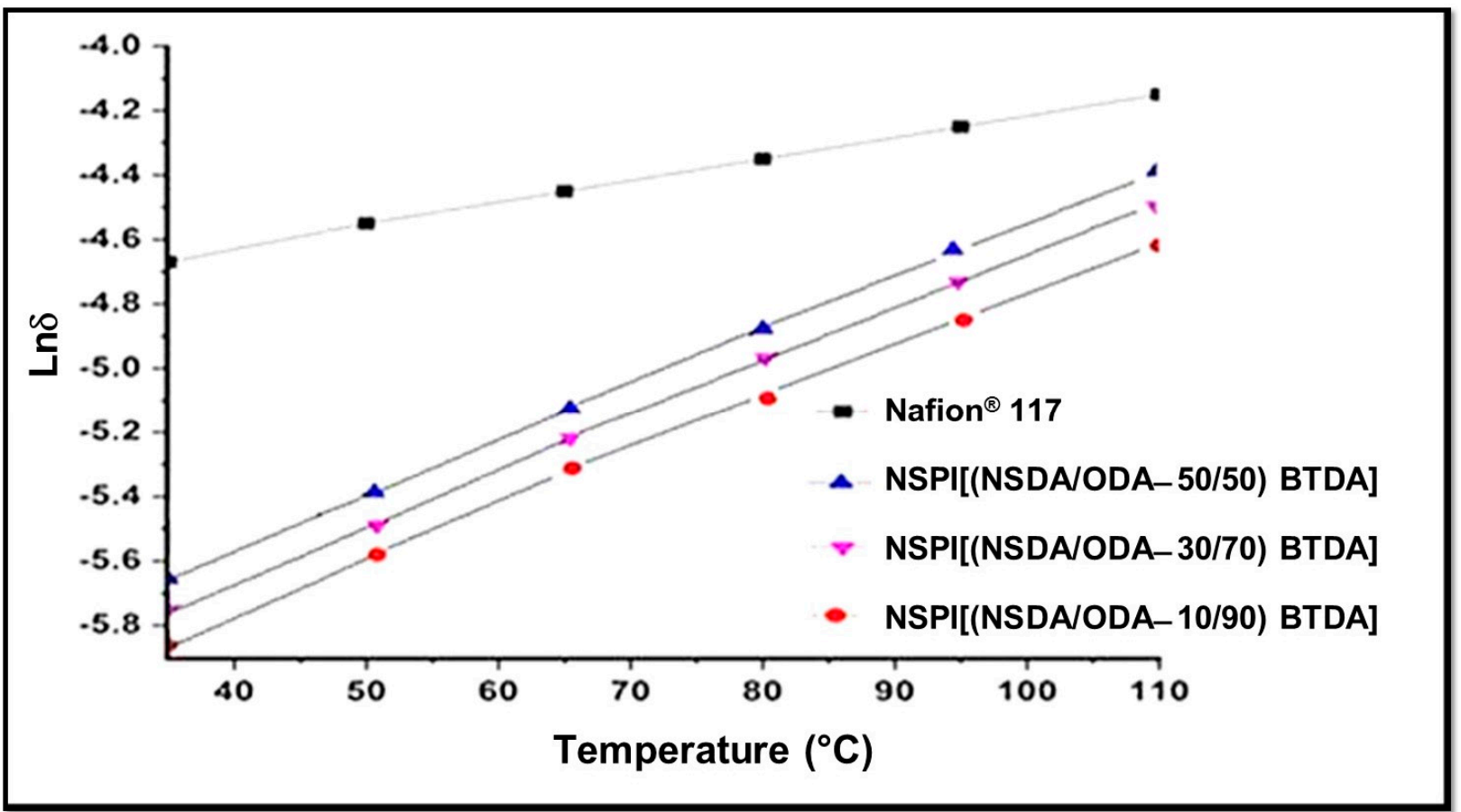

Figure 6. Proton conductivity of NSPIs film vs. Nafion ${ }^{\circledR} 117$.

\subsection{Fuel Cell Performance}

The performance of NSPI 10 (i.e., [(NSDA/ODA-10/90) BTDA]) and Nafion ${ }^{\circledR} 117$ at $70{ }^{\circ} \mathrm{C}$ in a direct methanol fuel cell (DMFC) is presented in Figure 7. Interestingly, the open circuit voltage in the case of NSPI 10 is found to be $0.65 \mathrm{~V}$, whereas it is lower for Nafion ${ }^{\circledR}$ $117(0.54 \mathrm{~V})$. The maximum power density of the NSPI 10 membrane $\left(28.5 \mathrm{~mW} . \mathrm{cm}^{-2}\right)$ is also higher compared to that of Nafion ${ }^{\circledR} 117\left(25 \mathrm{~mW} \cdot \mathrm{cm}^{-2}\right)$. In addition, the current density for NSPI $10\left(275 \mathrm{~mA} . \mathrm{cm}^{-2}\right)$ is higher compared to that of Nafion ${ }^{\circledR} 117\left(230 \mathrm{~mA} . \mathrm{cm}^{-2}\right)$. 


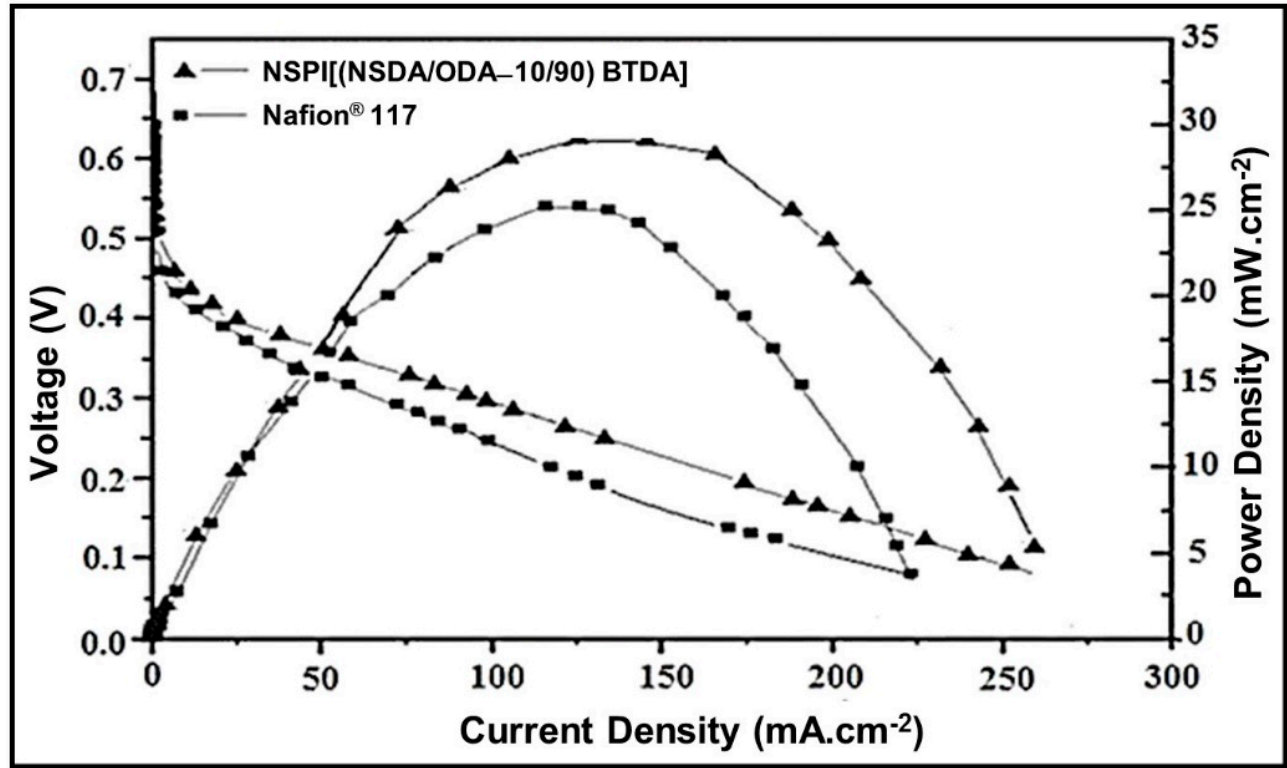

Figure 7. Evaluation of NSPI 10 and Nafion ${ }^{\circledR} 117$ membranes at $70{ }^{\circ} \mathrm{C}$ in DMFC.

Furthermore, it appears that the maximum power density of NSPI 10 increased from $28.5 \mathrm{~mW} . \mathrm{cm}^{-2}$ to $34.75 \mathrm{~mW} . \mathrm{cm}^{-2}$ with the rise in temperature from $70{ }^{\circ} \mathrm{C}$ to $140{ }^{\circ} \mathrm{C}$, which is clearly an indication of its stability and suitability for DMFC applications (Figure 8).

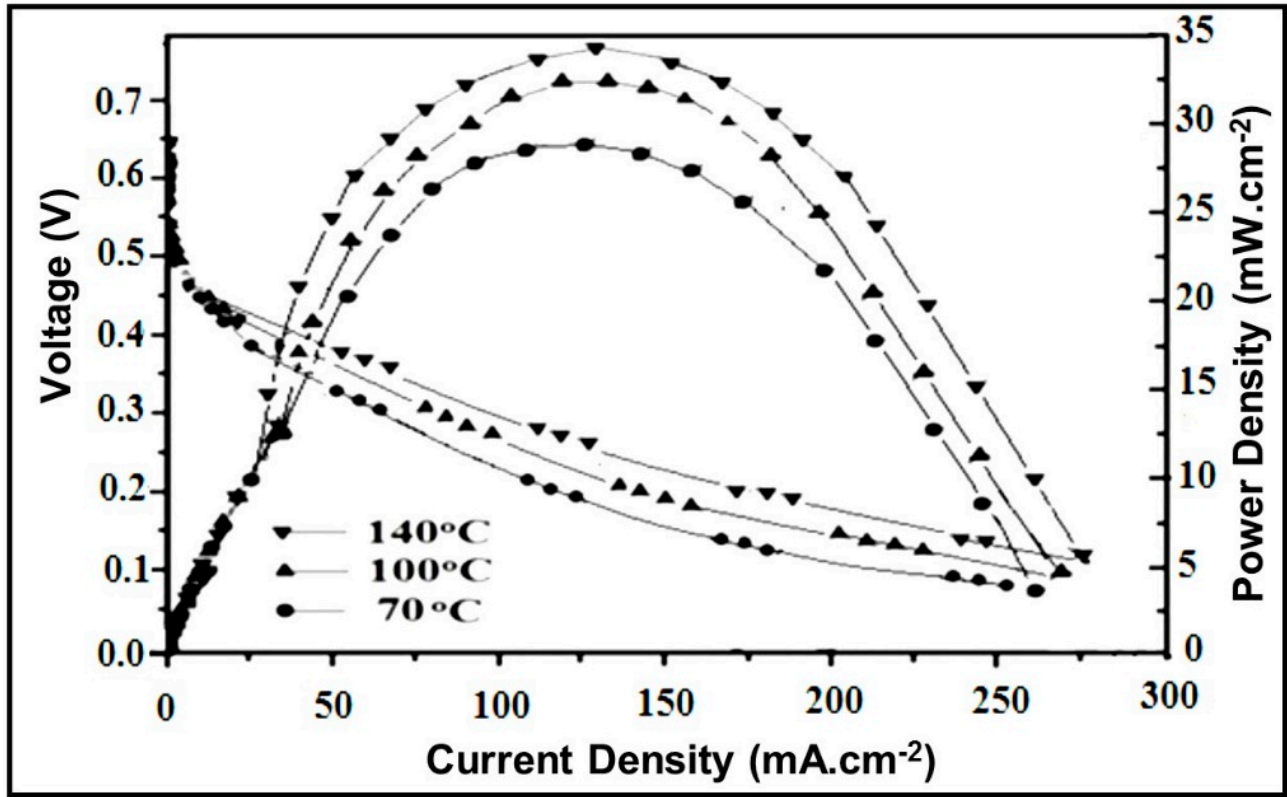

Figure 8. Evaluation of NSPI 10 membrane in DMFC at various indicated temperatures.

\section{Conclusions}

A diamine monomer containing benzenesulfonic acid (SDA) as a pendant group was successfully synthesized, as evidenced by ${ }^{13} \mathrm{C}$ NMR. NSPI was then prepared by the random copolymerization of BTDA, NSDA, and ODA via thermal imidization and confirmed by FTIR. The prepared NSPI membranes elicited a remarkable hydrolytic stability and a high proton conductivity at elevated temperatures. These characteristics make NSPIs suitable candidates to be used as PEMFCs for efficient renewable energy. 
Author Contributions: K.L., S.F., W.R., S.S., F.M., S.A.H.S., M.N., W.N.A., B.M. and M.F. have read and agreed to the published version of the manuscript. K.L. and S.F. performed most of the experiments; W.R. and F.M. supervised the project; All authors have formally analyzed and validated the data; K.L., S.F., W.R. and F.M. co-wrote and edited the manuscript; F.M. revised the manuscript and submitted it to the journal. All authors have read and agreed to the published version of the manuscript.

Funding: This research did not receive any specific grant from funding agencies in the public, commercial, or not-for-profit sectors.

Institutional Review Board Statement: Not applicable.

Informed Consent Statement: Not applicable.

Data Availability Statement: Not applicable.

Acknowledgments: FM thanks MDPI for the kind invitation to write and submit a manuscript on this topic to the special issue.

Conflicts of Interest: The authors declare no conflict of interest.

$\begin{array}{ll}\text { Abbreviations } \\ \text { BTDA } & 3,3^{\prime}, 4,4^{\prime} \text {-benzophenonetetracarboxylic dianhydride } \\ \text { DMFC } & \text { Direct methanol fuel cell } \\ \text { FTIR } & \text { Fourier-transform infrared spectroscopy } \\ \text { IEC } & \text { Ion exchange capacity } \\ \text { NMR } & \text { Nuclear magnetic resonance } \\ \text { NSDA } & \text { Novel sulfonated diamine } \\ \text { NSPAA } & \text { Novel sulfonated polyamic acid } \\ \text { NSPI } & \text { Novel sulfonated polyimide } \\ \text { ODA } & 4,4^{\prime} \text {-oxydianiline } \\ \text { PEMFC } & \text { Polymer electrolyte membrane fuel cell } \\ \text { RT } & \text { Room temperature } \\ \text { WU } & \text { Water uptake }\end{array}$

\section{References}

1. Pelletier, S.; Jabali, O.; Laporte, G. Goods distribution with electric vehicles: Review and research perspectives. Transp. Sci. 2016, 50, 3-22. [CrossRef]

2. Oh, B.H.; Kim, A.R.; Yoo, D.J. Profile of extended chemical stability and mechanical integrity and high hydroxide ion conductivity of poly(ether imide) based membranes for anion exchange membrane fuel cells. Int. J. Hydrog. Energy 2019, 44, 4281-4292. [CrossRef]

3. Sharaf, O.Z.; Orhan, M.F. An overview of fuel cell technology: Fundamentals and applications. Renew. Sustain. Energ. Rev. 2014, 32, 810-853. [CrossRef]

4. Wang, Y.; Chen, K.S.; Mishler, J.; Cho, S.C.; Adroher, X.C. A review of polymer electrolyte membrane fuel cells: Technology, applications, and needs on fundamental research. Appl. Energy 2011, 88, 981-1007. [CrossRef]

5. Hooshyari, K.H.; Javanbakht, M.; Naji, L.; Enhessari, M. Nanocomposite proton exchange membranes based on Nafion containing $\mathrm{Fe}_{2} \mathrm{TiO}_{5}$ nanoparticles in water and alcohol environments for PEMFC. J. Membr. Sci. 2014, 454, 74-81. [CrossRef]

6. Karimi, M.B.; Mohammadi, F.; Hooshyari, K.H. Recent approaches to improve Nafion performance for fuel cell applications: A review. Int. J. Hydrog. Energy 2019, 44, 28919-28938. [CrossRef]

7. Javanbakht, M.; Hooshyari, K.H.; Enhessari, M.; Beydaghi, H. Novel PVA/ $\mathrm{La}_{2} \mathrm{Ce}_{2} \mathrm{O}_{7}$ hybrid nanocomposite membranes for application in proton exchange membrane fuel cells. Iran. J. Hydrog. Fuel Cell 2014, 1, 105-112.

8. Attaran, A.M.; Javanbakht, M.; Hooshyari, K.H.; Enhessari, M. New proton conducting nanocomposite membranes based on poly vinyl alcohol/poly vinyl pyrrolidone $/ \mathrm{BaZrO}_{3}$ for proton exchange membrane fuel cells. Solid State Ion. 2015, 269, 98-105. [CrossRef]

9. $\quad$ Ping, L.; Wenji, W.; Jindun, L.; Benbing, S.; Yuqian, D.; Yifan, L.; Jingtao, W. Investigating the Nanostructures and Proton Transfer Properties of Nafion-GO Hybrid Membranes. J. Membr. Sci. 2018, 555, 327-336.

10. Weib, A.; Schindler, S.; Galbiati, S.; Danzer, M.; Zeis, R. Distribution of relaxation times analysis of high-temperature PEM fuel cell impedance spectra. Electrochim. Acta 2017, 230, 391-398. 
11. Kim, A.R.; Yoo, D.J. A comparative study on physiochemical, thermo mechanical, and electrochemical properties of sulfonated poly (ether ether ketone) block copolymer membranes with and without $\mathrm{Fe}_{3} \mathrm{O}_{4}$ nanoparticles. Polymers 2019, 11, 536. [CrossRef] [PubMed]

12. Kim, A.R.; Park, C.J.; Vinothkannan, M.; Dong, J.Y. Sulfonated poly ether sulfone / heteropoly acid composite membranes as electrolytes for the improved power generation of proton exchange membrane fuel cells. Compos. Part B Eng. 2018, 155, $272-281$. [CrossRef]

13. Date, B.; Han, J.; Park, S.; Park, E.J.; Shin, D.; Ryu, C.Y.; Bae, C. Synthesis, and morphology study of sebs triblock copolymers functionalized with sulfonate and phosphonate groups for proton exchange membrane fuel cells. Macromolecules 2018, 51, 1020-1030. [CrossRef]

14. Li, C.C.; Yang, Z.H.; Liu, X.P.; Zhang, Y.F.; Dong, J.M.; Zhang, Q.; Cheng, H.S. Enhanced performance of sulfonated poly (ether ether ketone) membranes by blending fully aromatic polyamide for practical application in direct methanol fuel cells (DMFCs). Int. J. Hydrog. Energy 2017, 42, 28567-28577. [CrossRef]

15. Zhuang, Y.; Seong, J.G.; Lee, Y.M. Polyimides containing aliphatic/alicyclic segments in the Main chains. Prog. Polym. Sci. 2019, 92, 35-88. [CrossRef]

16. Rusanov, A.L.; Bulycheva, E.G.; Bugaenko, M.G.; Leikin, A.Y.; Shevelev, S.A.; Dutov, M.D.; Serushkina, O.V.; Voitekunas, V.Y.; Abadi, M.J.P.S. New sulfonated polynaphthylimides: Synthesis and investigation. Polym. Sci. 2009, 51, 3-7. [CrossRef]

17. Perrot, C.; Gonon, L.; Marestin, C.; Gebel, G. Hydrolytic degradation of sulfonated polyimide membranes for fuel cells. J. Membr. Sci. 2011, 379, 207-214. [CrossRef]

18. Liaqat, K.; Rehman, W.; Saeed, S.; Waseem, M.; Fazil, S.; Shakeel, M.; Kang, P. Synthesis and characterization of novel sulfonated polyimide with varying chemical structure for fuel cell applications. Solid State Ion. 2018, 319, 141-147. [CrossRef]

19. Gao, C.; Chen, J.; Zhang, B.; Wang, L. Effect of chemical structure and degree of branching on the stability of proton exchange membranes based on sulfonated polynaphthylimides. Polymers 2020, 12, 652. [CrossRef] [PubMed]

20. Yi, L.; Huang, W.; Yan, D. Polyimides with side groups: Synthesis and effects of side groupson their properties. J. Polym. Sci. A Polym. Chem. 2017, 55, 533-559. [CrossRef]

21. Jang, W.; Lee, C.; Sundar, S.; Shul, Y.G.; Han, H. Thermal, and hydrolytic stability of sulfonated polyimide membranes with varying chemical structure. Polym. Degrad. Stab. 2005, 90, 431-440. [CrossRef]

22. Mandal, A.K.; Bisoi, S.; Banerjee, S.; Komber, H.; Voit, B. Sulfonated copolyimides containing trifluoromethyl and phosphine oxide moieties: Synergistic effect towards proton exchange membrane properties. Eur. Polym. J. 2017, 95, 581-595. [CrossRef]

23. Fang, J.; Guo, X.; Harada, S.; Watari, T.; Tanaka, K.; Kita, H.; Okamoto, K.I. Novel sulfonated polyimides as polyelectrolytes for fuel cell application. 1. Synthesis, proton conductivity and water stability of polyimides from 4, 4-diaminodiphenyl ether-2, 2-disulfonic acid. Macromolecules 2002, 35, 9022-9028. [CrossRef]

24. Yu, H.S.; Liu, Y.L.; Sun, Y.M.; Lai, J.Y.; Wang, D.M.; Liu, B.; Guiver, M.D.; Gao, Y. Proton exchange membranes modified with sulfonated silica nanoparticles for direct methanol fuel cells. J. Membr. Sci. 2007, 296, 21-28.

25. Kim, D.H.; Kim, S.C. Transport properties of polymer blend membranes of sulfonated and nonsulfonated polysulfones for direct methanol fuel cell application. Macromol. Res. 2008, 16, 457-466. [CrossRef]

26. Yang, S.J.; Jang, W.; Lee, C.; Shul, Y.G.; Han, H. The effect of crosslinked network with poly (ethylene glycol) on sulfonated polyimide for polymer electrolyte membrane fuel cell. J. Polym. Sci. B Polym. Phys. 2005, 43, 1455-1464. [CrossRef]

27. Savard, O.; Peckham, T.J.; Yang, Y.; Holdcroft, S. Structure-property relationships for a series of polyimide copolymers with sulfonated pendant groups. Polymers 2008, 49, 4949-4959. [CrossRef]

28. Wilson, D.; Stensenberger, H.D.; Hergenrother, P.M. Polyimides; Blackie: Glasgow, UK, 1990; pp. 129-157.

29. Pandey, R.P.; Shahi, V.K. Sulfonated imidized graphene oxide (SIGO) based polymer electrolyte membrane for improved water retention, stability and proton conductivity. J. Power Sources 2015, 299, 104-113. [CrossRef]

30. Genies, C.; Mercier, R.; Sillion, B.; Cornet, N.; Gebel, G.; Pineri, M. Soluble sulfonated naphthalenic polyimides as materials for proton exchange membranes. Polymer 2001, 42, 359-373. [CrossRef]

31. Umsarikaa, P.; Changkhamchoma, S.; Paradeea, N.; Sirivata, A.; Supaphola, P.; Hormnirunb, P. Proton exchange membrane based on sulfonated poly (aromatic imide-co-aliphatic imide) for direct methanol fuel cell. Mater. Res. 2018, 21, e20170823. [CrossRef]

32. Guo, Q.; Pintauro, P.N.; Tang, H.; Connor, S.O. Sulfonated and crosslinked Polyphosphazene-based proton-exchange membranes. J. Membr. Sci. 1999, 154, 175-181. [CrossRef]

33. Yin, Y.; Yamada, O.; Tanaka, K.; Okamoto, K. On the development of naphthalene-based sulfonated polyimide membranes for fuel cell applications. Polym. J. 2006, 38, 197-219. [CrossRef]

34. Zhang, G.; Guo, X.; Fang, J.; Chen, K.; Okamoto, K. Preparation, and properties of covalently cross-linked sulfonated copolyimide membranes containing benzimidazole groups. J. Membrane Sci. 2009, 326, 708-713. [CrossRef]

35. Sarkar, P.; Mohanty, A.K.; Bandyopadhyay, P.; Chattopadhyay, S.; Banerjee, S. Proton exchange properties of flexible diaminebased new fluorinated sulfonated polyimides. RSC Adv. 2014, 4, 11848-11858. [CrossRef]

36. Yin, Y.; Suto, Y.; Sakabe, T.; Chen, S.W.; Hayashi, S.; Mishima, T. Water Stability of Sulfonated Polyimide Membranes. Macromolecules 2006, 39, 1189-1198. [CrossRef]

37. Yin, Y.; Yamada, O.; Suto, Y.; Mishima, T.; Tanaka, K.; Kita, H. Synthesis and characterization of proton-conducting copolyimides bearing pendant sulfonic acid groups. J. Polym. Sci. Part A Polym. Chem. 2005, 43, 1545-1553. [CrossRef] 
38. Miyatake, K.; Zhou, H.; Matsuo, T.; Uchida, H.; Watanabe, M. Proton conductive polyimide electrolytes containing trifluoromethyl groups: Synthesis, properties, and DMFC performance. Macromolecules 2004, 37, 4961-4966. [CrossRef]

39. Yasuda, T.; Li, Y.; Miyatake, K.; Hirai, M.; Nanasawa, M.; Watanabe, M. Synthesis and properties of polyimides bearing acid groups on long pendant aliphatic chains. J. Polym. Sci. Part A Polym. Chem. 2006, 44, 3995-4005. [CrossRef]

40. Endo, N.; Matsuda, K.; Yaguchi, K.; Hu, Z.; Chen, K.; Higa, M. Cross-linked sulfonated polyimide membranes for polymer electrolyte fuel cells. J. Electrochem. Soc. 2009, 156, B628-B633. [CrossRef]

41. Tomkiewicz, M.; Sen, P.N. The Chemistry and Physics of Composite Media; The Electrochemical Society Inc.: Pennington, NJ, USA, 1985.

42. Divisek, J.; Eikerling, M.; Mazin, V.; Schmitz, H.; Stimming, U.; Volfkovich, Y.M. A study of capillary porous structure and sorption properties of nafion proton-exchange membranes swollen in water. J. Electrochem. Soc. 1998, 145, 2677-2684. [CrossRef]

43. Yin, Y.; Fang, J.; Watari, T.; Tanaka, K.; Kita, H.; Okamoto, K.I. Synthesis and properties of highly sulfonated proton conducting polyimides from bis (3-sulfopropoxy) benzidine diamines. J. Mater. Chem. 2004, 14, 1062-1070. [CrossRef] 